\title{
Measurement of Different Types of Potato Chips by Inductively Coupled Plasma-Optical Emission Spectrometer
}

\author{
AL-rajhi, M.A. \\ Physics Department, College of Science, Al Imam Mohammad Ibn Saud Islamic University, Riyadh, KSA \\ Email: rajhi.mai9@gmail.com
}

Received 18 March 2014; revised 18 April 2014; accepted 25 April 2014

Copyright (c) 2014 by author and Scientific Research Publishing Inc.

This work is licensed under the Creative Commons Attribution International License (CC BY).

http://creativecommons.org/licenses/by/4.0/

(c) (i) Open Access

\begin{abstract}
Potato chips are considered as one of the most popular and preferable children's foods in Saudi Arabia. The aim of this study was to examine the concentration of 12 chemical elements (i.e. $\mathrm{Cd}, \mathrm{Cr}$, $\mathrm{Cu}, \mathrm{Fe}, \mathrm{Mg}, \mathrm{Mn}, \mathrm{Ni}, \mathrm{Pb}, \mathrm{Zn}, \mathrm{As}$, Se and $\mathrm{Al}$ ) in different types of potato chips. Samples were analyzed using an Inductively Coupled Plasma-Optical Emission Spectrometer (ICP-OES). The average concentrations of analyzed elements in all potato chips were examined and compared with the recommendations of international organizations concerned with food safety. From the human health point of view, this investigation showed that there was no possible health risk to consumers due to the intake of potato chips.
\end{abstract}

\section{Keywords}

ICPI-OES, Potato Chips, Heavy and Essential Elements

\section{Introduction}

Inductively Coupled Plasma-Optical Emission Spectrometer is an analytical instrument used for the detection of metals in different environmental samples. It is a type of emission spectroscopy that uses the inductively coupled plasma to produce excited atoms and ions that emit electromagnetic radiation at wavelengths characteristic of a particular element. One of the advantages of inductively coupled plasma optical emission spectrometry (ICP-OES) as an analytical technique is that major, minor and trace element determinations can be performed simultaneously, thus minimizing sample handling and reducing sample contamination [1]. The concentration level of metals in foods are very importance due to the significant role of metal ions in health and diseas- 
es which include the requirement for intake of essential trace elements to the toxicity associated with high concentration of metals [2]. Some metals are important to human health (i.e. Fe, Se, Zn, and Cr), though they are potentially harmful if consumed in large quantities. Heavy metals like (Cd, As $\mathrm{Pb}$ ) are most serious contaminants for environment and human beings [3]. Once excessive significant metals enter in the soil, water or air, it's going to cause hazards to human health through consumption of food crops and vegetables cultivated in these contaminated environments. Some metals are important to human health (i.e. Fe, Se, $\mathrm{Zn}$, and $\mathrm{Cr}$ ), although they are potentially harmful if consumed in large quantities. Heavy metals such as ( $\mathrm{Cd}, \mathrm{As} \mathrm{Pb}$ ) are the most dangerous contaminants for environment and human beings 2 . Once excessive heavy metals enter in the soil, water or air, it may cause hazards to human health through consumption of food crops and vegetables cultivated in these contaminated environments [4]. Ingestion of contaminated food is one of the main routes through which heavy metals enter the human body [5]. Contamination of food can occur at any point in the production chain (i.e. from the raw materials, processing, packing, transportation, storage or marketing to consumption. Because of improper subject to contamination by microorganism, metals as well as pesticides. Obviously, data on the concentrations of metals in food items at the point of consumption are necessary for estimation human exposure to metals [6]. The toxicity of heavy metals might be by the displacement of physiologically applicable metal Cd can replace $\mathrm{Cu}$ and $\mathrm{Fe}$ in cytoplasmic and membrane proteins. Especially in the form of divalent, the free metal ions can support the generation of ultra-oxide and hydroxyl radical which, in turn, can lead to deterioration of lipids, nucleic acids and proteins [7]. The current study makes an attempt to measure the concentration of $\mathrm{Cd}, \mathrm{Cr}, \mathrm{Cu}$, $\mathrm{Fe}, \mathrm{K}, \mathrm{Mg}, \mathrm{Mn}, \mathrm{Ni}, \mathrm{Pb}, \mathrm{Zn}, \mathrm{As}$, Se, $\mathrm{Al}$ and $\mathrm{V}$ in potato chips by using ICP-OES.

\section{Material and Method}

\subsection{Study Area}

The study area is Riyadh City, the capital city of the Kingdom of Saudi Arabia with an area of about $1554 \mathrm{~km}^{2}$. It is located centrally in the Najd region and lies between latitude $34^{\circ}-38^{\circ}$ north and longitude $43^{\circ}-46^{\circ}$ east (Figure 1).

\subsection{Sample Collection}

A total of 13 types of potato chips were collected from the supermarkets around the city of Riyadh and transported in plastic bags to the Environmental Research Laboratory at Al Imam Mahammad Ibn Saud Islamic University for elemental analysis. Samples were dried, and after drying, samples were grained into a fine powder using a ceramic mill and stored in polyethylene bags until used for acid digestion.

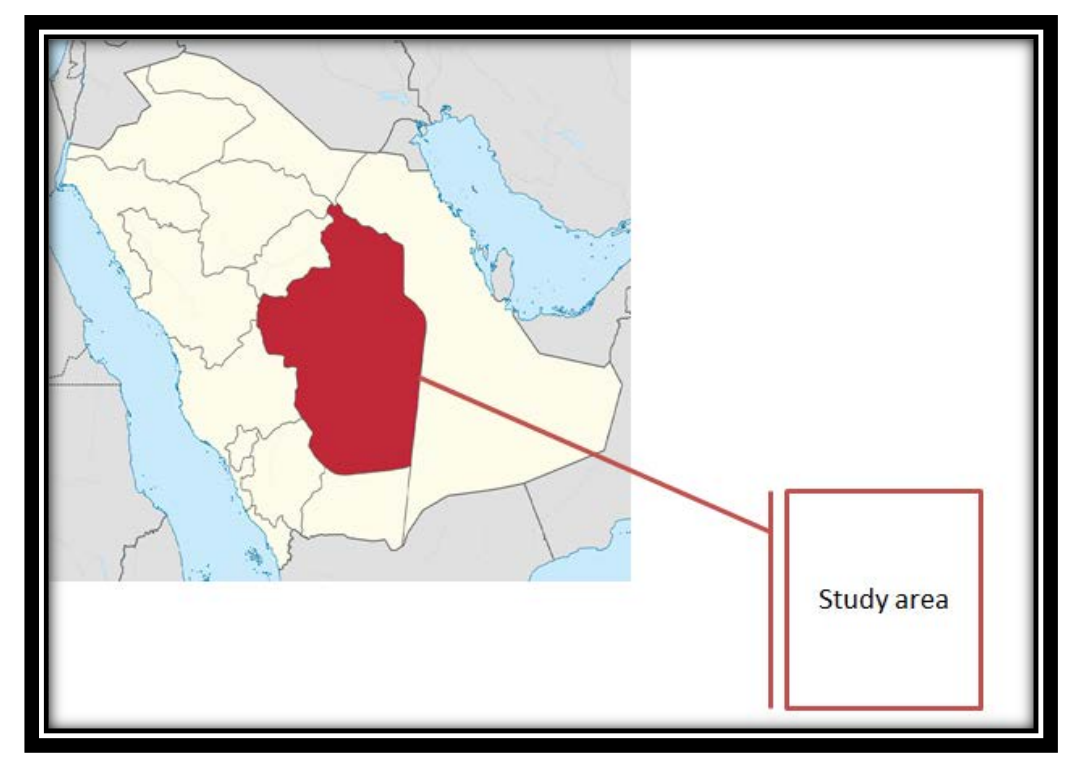

Figure 1. Kingdom of Saudi Arabia map showing the study area. 


\subsection{Sample Preparation}

$10 \mathrm{ml}$, high purity $\mathrm{HNO}_{3}$ and $2 \mathrm{ml} \mathrm{H}_{2} \mathrm{O}_{2}$ were added to the beaker containing $2 \mathrm{~g}$ of dry samples placed in the fume cupboard for two days for digestion. The mixture was then digested at $80^{\circ} \mathrm{C}$ till the transparent solution was achieved. After cooling, the digested samples were filtered using Buchner funnels and the filtrate was diluted to $50 \mathrm{ml}$ with distill water. The final solution were used for the elements analysis namely $\mathrm{Cd}, \mathrm{Cr}, \mathrm{Cu}, \mathrm{Fe}, \mathrm{K}$, $\mathrm{Mg}, \mathrm{Mn}, \mathrm{Ni}, \mathrm{Pb}, \mathrm{Zn}$, As, Se and Al by ICP optical emission spectrometer. The recovery values were nearly quantitative (95\%) for digestion method. The relative standard deviations were less than $10 \%$ for all investigated elements.

\subsection{Samples Measurement}

The measurements were performed using a GENESIS ICP optical emission spectrometer (SPECTRO Analytical Instruments, Kleve, Germany) with axial plasma observation. The instrument includes a Paschen-Runge mount spectrometer, constructed employing the Optimized Rowland Circle Alignment (ORCA) technique. It consists of two hollow section cast shells, designed for direct thermal stabilization and small volume. 15 pre-aligned linear CCD detectors are installed on the outside of the optics body, which allow fast, simultaneous spectrum capture of the wavelength range between $175 \mathrm{~nm}$ and $777 \mathrm{~nm}$. For UV access $(<200 \mathrm{~nm})$, the optical system purged with argon. The purge rate during normal operation is $0.5 \mathrm{~L} / \mathrm{min}$. To enable method transfer between individual instruments, ICAL (Intelligent Calibration Logic) was used to normalize the wavelength and the intensity scale of the optical system to a reference optic ("optic master"). Stability of the forward power in the case of rapidly changing sample loads was achieved through use of an air-cooled ICP-generator, based on a free running $27.12 \mathrm{MHz}$ system. All ICP operating parameters were software controlled. The ICP-OES instrument was initialized and allowed to achieve thermal equilibrium over $30 \mathrm{~min}$. Multi-element Solution Standards obtained from Agilent technology were used to calibrate and quantitative sample results. The lower detection limit values of the elements were found to be $0.001 \mathrm{mg} / \mathrm{kg}$ for $\mathrm{Cr}, 0.001 \mathrm{mg} / \mathrm{kg}$ for $\mathrm{Cu}, 0.0001 \mathrm{mg} / \mathrm{kg}$ for Zn, $0.002 \mathrm{mg} / \mathrm{kg}$ for $\mathrm{Fe}, 0.003 \mathrm{mg} / \mathrm{kg}$ for $\mathrm{V}, 0.0001 \mathrm{mg} / \mathrm{kg}$ for $\mathrm{Mn}, 0.0001 \mathrm{mg} / \mathrm{kg}$ for Cd, $0.001 \mathrm{mg} / \mathrm{kg}$ for $\mathrm{Al}, 0.001 \mathrm{mg} / \mathrm{kg}$ for Ni, $0.01 \mathrm{mg} / \mathrm{kg}$ for Se, 0.004 for $\mathrm{Pb}$ and $0.01 \mathrm{mg} / \mathrm{kg}$ for As in this study.

\subsection{Quality Assurance}

Appropriate quality assurance procedures and precautions were carried out to ensure the reliability of the results. During the experiments, all glass wares and equipments were carefully cleaned starting with $5 \% \mathrm{HNO}_{3}$ and ending with repeated rinsing distilled water to prevent contamination. Reagent blank determinations were used to correct the instrument readings. The lower detection limit values of the elements were found to be 0.001 $\mathrm{mg} / \mathrm{kg}$ for Cr, $0.001 \mathrm{mg} / \mathrm{kg}$ for $\mathrm{Cu}, 0.0001 \mathrm{mg} / \mathrm{kg}$ for Zn, $0.002 \mathrm{mg} / \mathrm{kg}$ for Fe, $0.003 \mathrm{mg} / \mathrm{kg}$ for V, $0.0001 \mathrm{mg} / \mathrm{kg}$ for $\mathrm{Mn}, 0.0001 \mathrm{mg} / \mathrm{kg}$ for $\mathrm{Cd}, 0.001 \mathrm{mg} / \mathrm{kg}$ for $\mathrm{Al}, 0.001 \mathrm{mg} / \mathrm{kg}$ for Ni, $0.01 \mathrm{mg} / \mathrm{kg}$ for Se, 0.004 for $\mathrm{Pb}$ and 0.01 $\mathrm{mg} / \mathrm{kg}$ for As in this study. The recovery values were nearly quantitative (95\%) for digestion method. The relative standard deviations were less than $10 \%$ for all investigated elements. Multi-element Solution Standards obtained from Agilent technology were used to calibrate and quantitative sample results.

\section{Result and Discussion}

Despite the remarkable improvement in the provision of healthy foods all over the world in recent decades, the prevalence of food contamination is still a source of concern in terms of health and economic consequences. For this reason, the present study aimed to analyze the heavy metals in different types of potato chips taken from the local markets in the capital of Saudi Arabia. The concentrations of essential elements in potato chips collected from different local markets of Riyadh are presented in Table 1. On average, the values obtained were 0.0001 $\mathrm{mg} / \mathrm{kg}$ for $\mathrm{Cu}, 0.0005 \mathrm{mg} / \mathrm{kg}$ for $\mathrm{Fe}, 0.0029 \mathrm{mg} / \mathrm{kg}$ for $\mathrm{Mn}, 0.0162 \mathrm{mg} / \mathrm{kg}$ for Ni, $0.0039 \mathrm{mg} / \mathrm{kg}$ for Zn, 0.0009 $\mathrm{mg} / \mathrm{kg}$ for $\mathrm{Cr}$ and $0.0200 \mathrm{mg} / \mathrm{kg}$ for Se. The results indicate that the order of concentrations of essential elements in potato chips showed the following trend: $\mathrm{Se}>\mathrm{Ni}>\mathrm{Zn}>\mathrm{Mn}>\mathrm{Cr}>\mathrm{Fe}>\mathrm{Cu}$. Comparing the results with the limits permitted by the World Health Organization and the Food and Agriculture Organization, it was found that the average concentrations of the obtained results for $\mathrm{Ni}, \mathrm{Zn}, \mathrm{Mn}, \mathrm{Se}, \mathrm{Cr}, \mathrm{Fe}$ and $\mathrm{Cu}$ were below the legal limits. This implies that chemical contamination was not present for any of the elements mentioned [8]-[10]. In contrast, some metals (e.g. $\mathrm{Cu}, \mathrm{Zn}, \mathrm{Fe}, \mathrm{Mn}$, Cretc.) are needed in the body in very small amounts (i.e. less than $100 \mathrm{mg} / \mathrm{kg}$ ) 
(Grivetti, 2000). It is important to evaluate the concentration of heavy metals in potato chips to report possible contamination that would represent a health hazard. The concentrations of heavy metals $\mathrm{Cd}, \mathrm{Al}, \mathrm{Pb}$ and $\mathrm{As}$ are presented in Table 2. The concentrations of $\mathrm{Cd}, \mathrm{Al}, \mathrm{Pb}$ and As ranged from $0.0001-0.0006 \mathrm{mg} / \mathrm{kg}, 0.0025$ $0.0114 \mathrm{mg} / \mathrm{kg}, 0.0014-0.0062 \mathrm{mg} / \mathrm{kg}$ and $0.0105-0.0712 \mathrm{mg} / \mathrm{kg}$, respectively. On average, the values obtained were $0.0001 \mathrm{mg} / \mathrm{kg}$ for $\mathrm{Cd}, 0.0056 \mathrm{mg} / \mathrm{kg}$ for $\mathrm{Al}, 0.0026 \mathrm{mg} / \mathrm{kg}$ for $\mathrm{Pb}$ and $0.0212 \mathrm{mg} / \mathrm{kg}$ for As. From the results of heavy metal measurements, the order of concentrations in potato chips showed the following trend: As > $\mathrm{Al}>\mathrm{Pb}>\mathrm{Cd}$. Heavy metals can be very harmful even at low concentrations when ingested over a long time period [11] [12]. According to the World Health Organization's and Food and Agriculture Organization's permissible limits of heavy metal in foodstuffs, obviously the average concentrations of $\mathrm{As}, \mathrm{Al}, \mathrm{Pb}$ and $\mathrm{Cd}$ fall far

Table 1. Concentration and statistical summary of $\mathrm{Cu}, \mathrm{Fe}, \mathrm{Mn}, \mathrm{Ni}, \mathrm{Zn}, \mathrm{Se}$ and $\mathrm{Cr}$ in potato chips samples.

\begin{tabular}{|c|c|c|c|c|c|c|c|}
\hline Samples No & $\mathrm{Cu}$ & $\mathrm{Fe}$ & $\mathrm{Mn}$ & $\mathrm{Ni}$ & $\mathrm{Zn}$ & Se & $\mathrm{Cr}$ \\
\hline 1 & 0.0002 & 0.0002 & 0.0017 & 0.0127 & 0.0023 & 0.0111 & 0.0006 \\
\hline 2 & 0.0000 & 0.0005 & 0.0008 & 0.0154 & 0.0017 & 0.0177 & 0.0011 \\
\hline 3 & 0.0000 & 0.0002 & 0.0012 & 0.0139 & 0.0036 & 0.0134 & 0.0008 \\
\hline 4 & 0.0006 & 0.0002 & 0.0027 & 0.0109 & 0.0027 & 0.0641 & 0.0005 \\
\hline 5 & 0.0000 & 0.0004 & 0.0010 & 0.0180 & 0.0032 & 0.0165 & 0.0003 \\
\hline 6 & 0.0003 & 0.0007 & 0.0011 & 0.0167 & 0.0024 & 0.0469 & 0.0004 \\
\hline 7 & 0.0000 & 0.0007 & 0.0009 & 0.0183 & 0.0022 & 0.0136 & 0.0004 \\
\hline 8 & 0.0001 & 0.0004 & 0.0006 & 0.0114 & 0.0008 & 0.0103 & 0.0006 \\
\hline 9 & 0.0000 & 0.0004 & 0.0008 & 0.0082 & 0.0012 & 0.0111 & 0.0007 \\
\hline 10 & 0.0001 & 0.0002 & 0.0029 & 0.0104 & 0.0027 & 0.0135 & 0.0006 \\
\hline 11 & 0.0001 & 0.0003 & 0.0049 & 0.0154 & 0.0034 & 0.0137 & 0.0004 \\
\hline 12 & 0.0001 & 0.0005 & 0.0040 & 0.0157 & 0.0024 & 0.0107 & 0.0005 \\
\hline 13 & 0.0000 & 0.0021 & 0.0147 & 0.0434 & 0.0224 & 0.0176 & 0.0044 \\
\hline Min & 0.0000 & 0.0002 & 0.0006 & 0.0082 & 0.0008 & 0.0103 & 0.0003 \\
\hline Max & 0.0006 & 0.0021 & 0.0147 & 0.0434 & 0.0224 & 0.0641 & 0.0044 \\
\hline Average & 0.0001 & 0.0005 & 0.0029 & 0.0162 & 0.0039 & 0.0200 & 0.0009 \\
\hline Std & 0.0002 & 0.0005 & 0.0038 & 0.0087 & 0.0056 & 0.0111 & 0.0011 \\
\hline
\end{tabular}

Table 2. Concentration and statistical summary of $\mathrm{Cd}, \mathrm{Al}, \mathrm{Pb}$ and $\mathrm{As}$ in potato chips samples.

\begin{tabular}{|c|c|c|c|c|}
\hline Samples No & Cd & Al & $\mathbf{P b}$ & As \\
\hline 1 & 0.0002 & 0.0025 & 0.0022 & 0.0112 \\
\hline 2 & 0.0000 & 0.0027 & 0.0015 & 0.0188 \\
\hline 3 & 0.0000 & 0.0026 & 0.0014 & 0.0136 \\
\hline 4 & 0.0006 & 0.0025 & 0.0062 & 0.0712 \\
\hline 5 & 0.0000 & 0.0113 & 0.0020 & 0.0177 \\
\hline 6 & 0.0003 & 0.0026 & 0.0052 & 0.0517 \\
\hline 7 & 0.0000 & 0.0114 & 0.0014 & 0.0141 \\
\hline 8 & 0.0001 & 0.0082 & 0.0023 & 0.0105 \\
\hline 9 & 0.0000 & 0.0039 & 0.0015 & 0.0115 \\
\hline 10 & 0.0001 & 0.0026 & 0.0026 & 0.0142 \\
\hline 11 & 0.0001 & 0.0074 & 0.0015 & 0.0139 \\
\hline 12 & 0.0001 & 0.0053 & 0.0018 & 0.0107 \\
\hline 13 & 0.0000 & 0.0098 & 0.0037 & 0.0170 \\
\hline Min & 0.0001 & 0.0025 & 0.0014 & 0.0105 \\
\hline Max & 0.0006 & 0.0114 & 0.0062 & 0.0712 \\
\hline Average & 0.0001 & 0.0056 & 0.0026 & 0.0212 \\
\hline Std & 0.0002 & 0.0025 & 0.0022 & 0.0112 \\
\hline
\end{tabular}


below the allowable limit [13]. The regression analysis showed that a significant correlation was noted between $\mathrm{Ni}$ and Zn (Figure 2), Ni and Mn (Figure 3), Mn and Fe (Figure 4) and Se and As (Figure 5), and a positive correlation was reported between $\mathrm{Se}$ and $\mathrm{Pb}$, as shown in Figure 6.

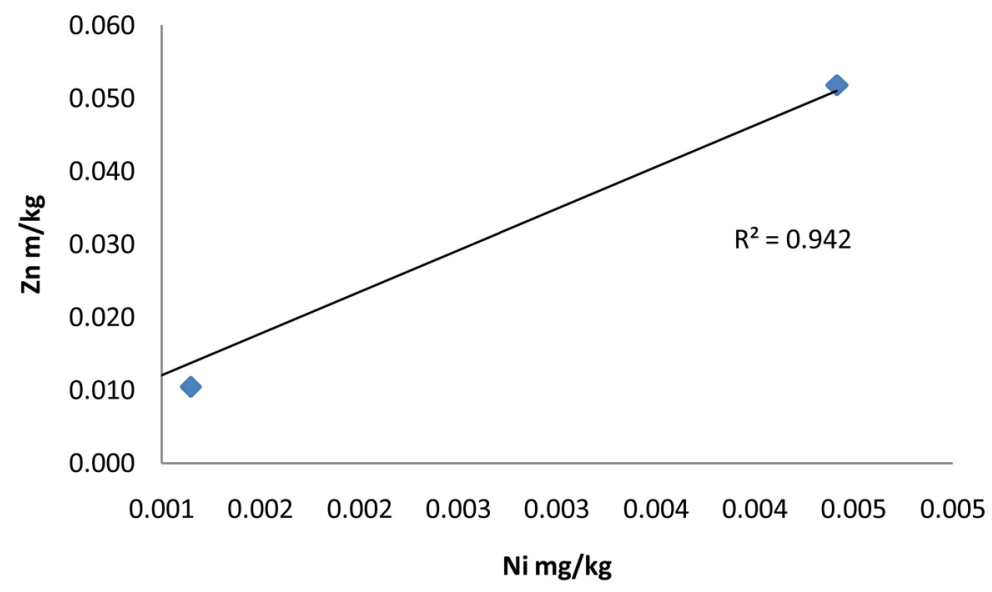

Figure 2. Ni concentration as function of $\mathrm{Z}$ concentration.

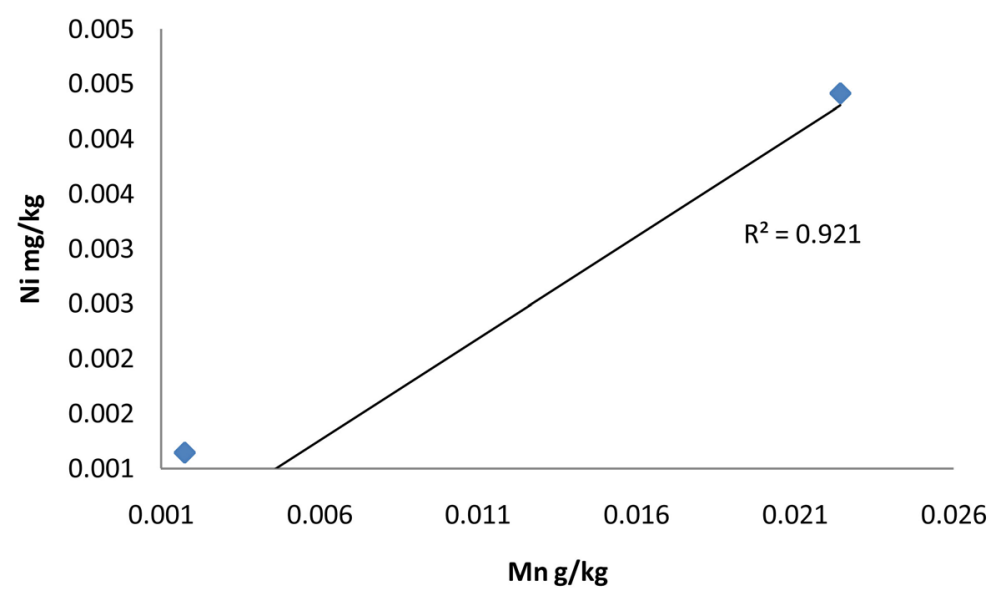

Figure 3. Mn concentration as function of Ni concentration.

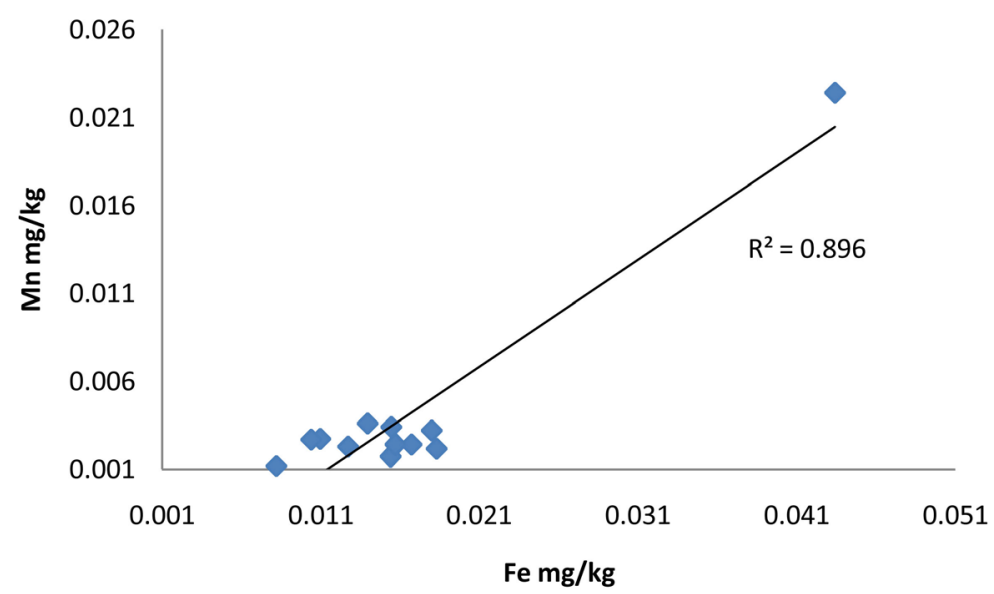

Figure 4. Fe concentration as function of Mn concentration. 


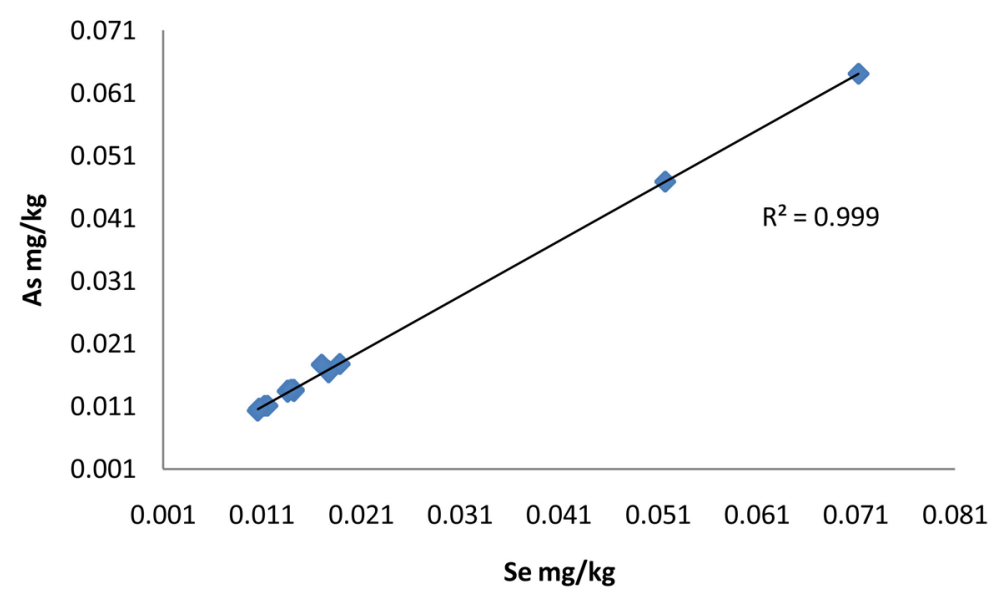

Figure 5. Se concentration as function of As concentration.

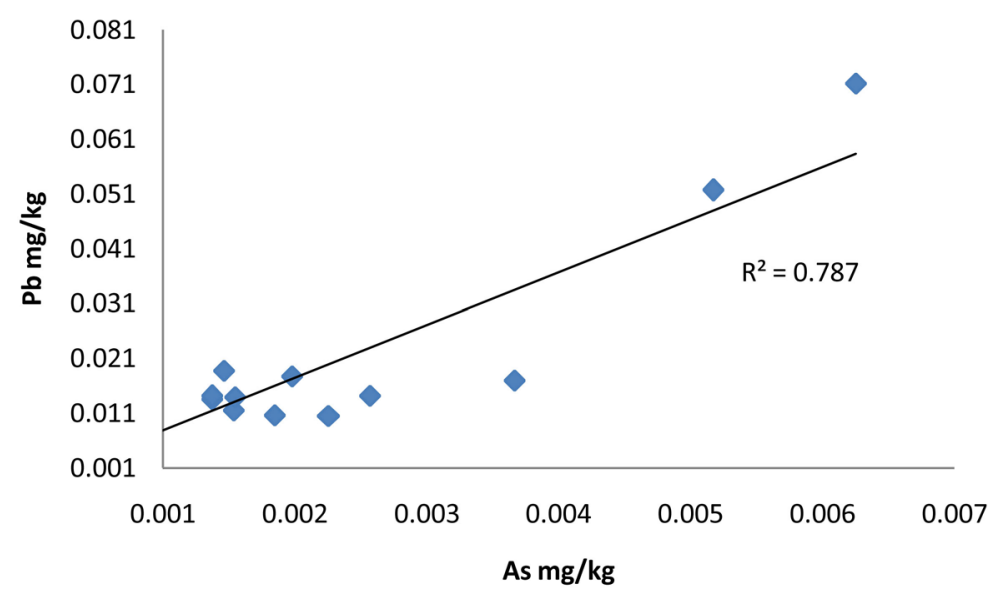

Figure 6. As concentration as function of $\mathrm{Pb}$ concentration.

\section{Conclusions}

From measurements of trace element and heavy metal concentration in potato chips purchased from the local market of Riyadh city. To sum up, the following conclusions can be drawn:

- No contamination have been observed in all samples analyzed;

- The essential elements concentration found to be in good level;

- The heavy metal concentration element concentration found to be within the acceptable recommended standard level given by FAO and WHO.

\section{Acknowledgments}

The author would like to thank many colleagues at AL imam Mohammad Ibn Saud Islamic University for their valuable help with these experiments.

\section{References}

[1] Stefánsson, A., Gunnarsson, I. and Giroud, N. (2007) New Methods for the Direct Determination of Dissolved Inorganic, Organic and Total Carbon in Natural Waters by Reagent-Free Ion Chromatography and Inductively Coupled Plasma Atomic Emission Spectrometry. Analytica Chimica Acta, 582, 69-74. http://dx.doi.org/10.1016/j.aca.2006.09.001

[2] Hague, T., Petrocozi, A., Andrews, P.L.R., Baker, J. and Noughton, D.P. (2008) Determination of Metal ion Content of Beverages and Estimation of target Hazard Quotient: A Comparative Study. Chemistry Central Journal, 2, 13. 
http://dx.doi.org/10.1186/1752-153X-2-13

[3] Bradl, H.B. (2005) Heavy Metals in the Environment: Origin, Interaction and Remediation. Elsevier, Amsterdam Press.

[4] Huang, M., Zhou, S., Sun, B. and Zhao, Q. (2008) Heavy Metals in Wheat Grain: Assessment of Potential Health Risk for Inhabitants in Kunshan, China. Science of the Total Environment, 405, 54-61.

[5] Grasmück, D. and Scholz, R.W. (2005) Risk Perception of Heavy Metal Soil Contamination by High-Exposed and Low-Exposed Inhabitants: The Role of Knowledge and Emotional Concerns. Risk Analysis, 25, 611-622.

[6] Iwegbue, C.M.A. (2011) Concentrations of Selected Metals in Candies and Chocolates Consumed in Southern Nigeria. Food Additives and Contaminants Part B, 4, 22-27. http://dx.doi.org/10.1080/19393210.2011.551943

[7] Marias, A.D. and Blackhurst, D.M. (2009) Do Heavy Metal Counter the Potential Health Benefits of Wine? Journal of Endocrinology, Metabolism and Diabetes of South Africa, 14, 77-79.

[8] Institute of Medicine (IOM) (2002) Dietary Reference Intakes for Vitamin A, Vitamin K, Arsenic, Boron, Chromium, Copper, Iodine, Iron, Manganese, Molybdenum, Nickel, Silicon, Vanadium, and Zinc. Washington DC: Institute of Medicine of theNational Academies, The National Academy Press, 2001 Constitution Avenue, 773.

[9] Institute of Medicine (IOM) (2003) Dietary Reference Intakes Applications in Dietary Planning Subcommittee on Interpretation and Uses of Dietary Reference Intakesthe Standing Committee on the Scientific Evaluation of Dietary Referenceintakes. Washington DC: Institute of Medicine of the National Academies, The National Academies Press, 248. for Some Elements.

[10] Joint Fao/Who Food Standards Programme Codex Committee on Contaminants in Foods Fifth Session The Hague, The Netherlands, 21-25 March 2011.

[11] Unak, P., Lambrecht, F.Y., Biber, F.Z. and Darcan, S. (2007) Iodine Measurements by Isotope Dilution Analysis in Drinkingwater in Western Turkey. Journal of Radioanalytical and Nuclear Chemistry, 273, 649-651. http://dx.doi.org/10.1007/s10967-007-0925-3

[12] Suppin, D., Zahlbracker, R., Krapfenbaurer-Coemak, G.H., Hassam-Hawer, C.H. and Smulders, F.J.M. (2005) Mercury, Lead and Cadmium Content of Fresh and Canned Fish Collected from Austrian Retail Operation. Ernahrung/Nutrition, 29, 456-460.

[13] Codex Alimentarius Commission (CAC) (2003) Evaluation of Certain Food Additives and Contaminants. FAO/WHO, Codex Stan. 230-2001, Rev, 1-2003, Rome. 